\title{
Studies on the enteropathy associated with primary hypogammaglobulinaemia
}

\author{
K Teahon, A D Webster, A B Price, J Weston, I Bjarnason
}

\begin{abstract}
Twelve patients with primary hypogammaglobulinaemia with diarrhoea not associated with known microbial pathogens were investigated. Histological evidence of inflammation was common in the stomach and jejunum. Moreover, eight of 10 patients undergoing colonoscopy had low grade 'microscopic colitis' with raised intraepithelial lymphocytes and an intact crypt architecture. Five of 12 patients had small intestinal inflammation on 111indium leucocyte scintigrams and all had increased faecal excretion (normal $<1 \%$ ) of 111 indium (over four days), which varied in intensity from mild (faecal excretion of ${ }^{111}$ indium $=1-3 \%$ ) to that comparable with moderately active (7-14.5\%) Crohn's disease. Three patients had small intestinal strictures superficially resembling Crohn's disease. Histologically, however, these lacked characteristic diagnostic features of Crohn's disease in two and the third patient had non-steroidal antiinflammatory drug induced diaphragm like strictures. Six of seven who were most severely symptomatic were successfully treated with an elemental diet with rapid improvement of symptoms. The faecal excretion of ${ }^{111}$ indium was repeated in five and all improved but histologically the colitis remained unchanged. These studies show that some patients with primary hypogammaglobulinaemia have intestinal inflammation unlike that found in classic inflammatory bowel disease. Elemental diet is a useful temporary measure in the treatment of these patients.
\end{abstract}

(Gut 1994; 35: 1244-1249)

Departments of Clinical Immunology A D Webster

and Histopathology, MRC Clinical

Research Centre, Harrow, Middlesex A B Price

J Weston

Department of Clinical Biochemistry, King's College School of Medicine, London I Bjarnason

Correspondence to: Dr K Teahon, Wolfson Unit of Clinical Pharmacology, University of Newcastle upon Tyne, Claremount Place, Newcastle upon Tyne NE2 4LP.

Accepted for publication 21 December 1993

A variety of intestinal abnormalities have been described in patients with primary hypogammaglobulinaemia. Patients with selective immunoglobulin A deficiency have an increased prevalence of coeliac disease ${ }^{12}$ and patients with common variable immunodeficiency often develop atrophic gastritis and are at increased risk of gastric carcinoma. ${ }^{3-5}$ In the small intestine, lymphoid nodular hyperplasia occurs with some regularity but is generally thought to be benign and of no clinical significance. ${ }^{1346}$ At least $10 \%$ of patients, however, with hypogammaglobulinaemia have unexplained severe diarrhoea, abdominal pain, or wasting, or all three, clinically reminiscent of that seen in patients with the acquired immunodeficiency syndrome. ${ }^{7}$
In 1972 Ament reported a gastrointestinal study of 39 patients with either $x$-linked agammaglobulinaemia or common variable immunodeficiency. ${ }^{8}$ Thirty were asymptomatic and of these three had Giardia lamblia and nine had a low grade colitis. Eight of nine symptomatic patients had Giardia lamblia. Most of the published work on intestinal function is confined to individual case reports. ${ }^{4-19}$ Collectively these suggest that patients with common variable immunodeficiency have jejunal histological findings ranging from normal to subtotal villous atrophy. Those with the most severe abnormalities may or may not respond to a gluten free diet. The precise relation to coeliac disease is, however, confounded by the fact that in only one patient was the diagnosis established with jejunal biopsies after gluten withdrawal and challenge. ${ }^{19}$ Curiously there have been six case reports of Crohn's like lesions in patients with $\mathrm{x}$-linked agammaglobulinaemia or common variable immunodeficiency. ${ }^{22-25}$ These have usually presented as diarrhoea with intestinal strictures and histological examination has shown transmural inflammation, usually without granulomata.

The natural history of hypogammaglobulinaemia has been radically changed over the last decade by the use of intravenous gammaglobulins. ${ }^{7}$ This seems to have virtually eradicated Giardia lamblia as an intestinal pathogen in patients in the United Kingdom as in our clinic only one in about 100 patients has been positive during the past six years. The incidence, however, of other causes of diarrhoea and weight loss have not changed. We therefore investigated a group of patients with significant symptoms to define the nature of gastrointestinal pathology and to test the effect of treatment with an elemental diet that has been effective in Crohn's disease. ${ }^{26} 27$

\section{Methods}

SUBJECTS

The immunodeficiency clinic at Northwick Park Hospital has a special interest in $x$-linked agammaglobulinaemia and common variable immunodeficiency with about 100 outpatients attending for regular follow up. Over a 12 month period all adult patients with pan hypogammaglobulinaemia presenting with persistent or intermittent gastrointestinal symptoms of abdominal pain or diarrhoea, in whom repeated courses of antimicrobial treatment had been ineffective were investigated. Evidence of small intestinal bacterial overgrowth, which included both a 
TABLE I Clinical details and investigational findings in patients with hypogammaglobulinaemia

\begin{tabular}{|c|c|c|c|c|c|c|c|c|c|}
\hline No & Sex & Diagnosis & $\begin{array}{l}\text { Clinical } \\
\text { presentation }\end{array}$ & $\begin{array}{l}\text { Faecal } \\
\text { excretion of } \\
\text { 111indium }(\%) \\
(n<1 \cdot 0 \%)\end{array}$ & $\begin{array}{l}\text { Localisation of } \\
\text { inflammation on } \\
\text { scintigraphy }\end{array}$ & Stomach & $\begin{array}{l}\text { Upper small } \\
\text { intestine } \\
\text { Duodenum (D) } \\
\text { fejunum (f) }\end{array}$ & Colon & Special features \\
\hline 1 & $\mathbf{F}$ & CVID & $\begin{array}{l}\text { Weight loss } \\
\text { diarrhoea }\end{array}$ & $4 \cdot 3$ & Indeterminate & Increased IEL & $\begin{array}{l}\text { Subtotal villous } \\
\text { atrophy excess } \\
\text { IEL (D + ) }\end{array}$ & $\begin{array}{l}\text { Colitis (UC like) } \\
\text { excess IEL }\end{array}$ & \\
\hline 2 & $\mathbf{M}$ & CVID & $\begin{array}{l}\text { Weight loss } \\
\text { diarrhoea }\end{array}$ & $7 \cdot 2$ & Indeterminate & $\begin{array}{l}\text { Erosive pan } \\
\text { gastritis }\end{array}$ & $\begin{array}{l}\text { Subtotal villous } \\
\text { atrophy }(D+J)\end{array}$ & $\begin{array}{l}\text { Microscopic pan } \\
\text { colitis }\end{array}$ & \\
\hline 3 & $\mathbf{F}$ & CVID & $\begin{array}{l}\text { Weight loss } \\
\text { diarrhoea }\end{array}$ & $5 \cdot 9$ & Indeterminate & Normal & Normal $(D+J)$ & $\begin{array}{l}\text { Microscopic pan } \\
\text { colitis excess IEL }\end{array}$ & \\
\hline 4 & $\mathrm{~F}$ & CVID & $\begin{array}{l}\text { Weight loss } \\
\text { diarrhoea } \\
\text { abdominal pain }\end{array}$ & $10 \cdot 9$ & Ileal & Normal & $\begin{array}{l}\text { Mild partial villous } \\
\text { atrophy (D) }\end{array}$ & $\begin{array}{l}\text { Microscopic distal } \\
\text { colitis excess IEL }\end{array}$ & $\begin{array}{l}\text { Extensive lymphoid } \\
\text { nodular hyperplasia }\end{array}$ \\
\hline 5 & F & CVID & $\begin{array}{l}\text { Weight loss } \\
\text { abdominal pain } \\
\text { receiving } \\
\text { prednisolone } \\
10 \mathrm{mg} / \text { day }\end{array}$ & $14 \cdot 5$ & Ileal & Normal & $\begin{array}{l}\text { Mild partial villous } \\
\text { atrophy and } \\
\text { inflammation (D) } \\
\text { J: normal }\end{array}$ & Normal & $\begin{array}{l}\text { Postmortem examination of } \\
\text { the ileum showed thin } \\
\text { walled band like strictures } \\
\text { and non-specific transmural } \\
\text { inflammation }\end{array}$ \\
\hline 6 & $\mathbf{F}$ & CVID & $\begin{array}{l}\text { Weight loss } \\
\text { diarrhoea } \\
\text { receiving } \\
\text { NSAID }\end{array}$ & $12 \cdot 7$ & Ileal & $\begin{array}{l}\text { Atrophic } \\
\text { gastritis }\end{array}$ & Normal (D) & $\begin{array}{l}\text { Microscopic pan } \\
\text { colitis excess IEL }\end{array}$ & $\begin{array}{l}\text { Ileoscopy showed typical } \\
\text { NSAID strictures with } \\
\text { ulceration }\end{array}$ \\
\hline 7 & $\mathbf{M}$ & XLA & $\begin{array}{l}\text { Weight loss } \\
\text { abdominal pain }\end{array}$ & $10 \cdot 8$ & Small bowel & Not done & Not done & Not done & $\begin{array}{l}\text { Resected jejunum had } \\
\text { multiple strictures and } \\
\text { non-specific transmural } \\
\text { inflammation }\end{array}$ \\
\hline 8 & $\mathbf{M}$ & XIA & $\begin{array}{l}\text { Recurrent } \\
\text { diarrhoea }\end{array}$ & $8 \cdot 8$ & Ileal & Not done & Not done & Not done & \\
\hline 9 & $\mathbf{F}$ & CVID & $\begin{array}{l}\text { Asymptomatic } \\
\text { recurrent } \\
\text { diarrhoea }\end{array}$ & $2 \cdot 2$ & Normal & Normal & $\begin{array}{l}\text { Mild duodenitis } \\
\text { (D) }\end{array}$ & Excess IEL & \\
\hline 10 & $\mathbf{M}$ & CVID & $\begin{array}{l}\text { Asymptomatic } \\
\text { recurrent } \\
\text { diarrhoea }\end{array}$ & $1 \cdot 6$ & Normal & $\begin{array}{l}\text { Atrophic HP } \\
\text { gastritis } \\
\text { Dysplasia }\end{array}$ & $\begin{array}{l}\text { Mild duodenitis } \\
\text { (D) }\end{array}$ & $\begin{array}{l}\text { Microscopic pan } \\
\text { colitis excess IEL }\end{array}$ & \\
\hline 11 & $\mathbf{M}$ & CVID & $\begin{array}{l}\text { Asymptomatic } \\
\text { recurrent } \\
\text { diarrhoea }\end{array}$ & $1 \cdot 1$ & Normal & Not done & Not done & $\begin{array}{l}\text { Mild distal colitis } \\
\text { excess IEL }\end{array}$ & \\
\hline 12 & $\mathrm{~F}$ & CVID & $\begin{array}{l}\text { Asymptomatic } \\
\text { recurrent } \\
\text { anaemia }\end{array}$ & $2 \cdot 3$ & Normal & Not done & Not done & $\begin{array}{l}\text { Proctitis excess } \\
\text { IEL }\end{array}$ & \\
\hline
\end{tabular}

HP: Helicobacter pylori; IEL: intraepithelial lymphocytes; CVID: common variable immunodeficiency; XLA: $x$-linked agammaglobulinaemia; UC: ulcerative colitis.

${ }^{14} \mathrm{C}$ carbon labelled glycocholic acid breath test and urinary indicans had been negative and there was no evidence of intestinal infection (stool for salmonella, shigella, campylobacter, ova, cysts, and parasites repeatedly negative) or enterotoxins in stool. Twelve patients were studied (seven females and five males), mean (SD) age 53 (13) years. Table I shows the clinical details. All were receiving regular intravenous gammaglobulins (Sandoglobulin, Sandoz Pharmaceuticals, Frimley, Surrey, UK), which contains immunoglobulin $G$ and only traces of immunoglobulin $\mathrm{A}$ and $\mathrm{M}$.

Informed consent was obtained from all patients and the studies were approved by Harrow Health Authority ethical committee.

\section{INVESTIGATIONS}

All patients were admitted to a metabolic research ward for the studies. All underwent 111 indium autologous leucocyte studies entailing abdominal scans within four hours of receiving the cells, to localise the inflammation and a four day faecal collection to quantitate the inflammatory activity as previously described. ${ }^{28}$ The estimated radiation dose received, assuming that $300 \mathrm{mCi}(11 \mathrm{MBq})$ dose of $111_{\text {indium leucocytes is injected is }}$ 8.5 milli Sieverts.

Ten patients had a full colonoscopy with serial biopsies after completion of the above studies and a gastroduodenoscopy with a biopsy specimen taken from the duodenum, antrum, and body. A Crosby capsule jejunal biopsy specimen was subsequently taken under $x$ ray control adjacent to the ligament of Trietz. Patients with abdominal pain had small intestinal barium examinations (follow through or enteroclysis) and all had a lactose tolerance test.

\section{TREATMENT}

Patients 1-7 (Table I), with the most severe symptoms were treated with an elemental diet as previously described in patients with Crohn's disease. ${ }^{26} 27$ Patients were discharged from hospital when they could manage the diet themselves.

\section{Results}

${ }^{11}$ INDIUM LEUCOCYTE STUDIES

${ }^{111}$ Indium leucocyte scintigrams showed early localisation of inflammation in five patients (ileal in four and small intestinal in one). Figure 1 shows a representative scintigram. In a further three patients the 20 hour abdominal scintigrams were abnormal but precise localisation to the small intestine was not possible. Table I shows that the four day faecal excretion of ${ }^{111}$ indium leucocytes was increased in all $(n<1 \%)$, ranging from mild inflammation ( 111 indium excretion $1-3 \%$ ) to that comparable with moderately active Crohn's disease and ulcerative colitis (7-14.5\%). 


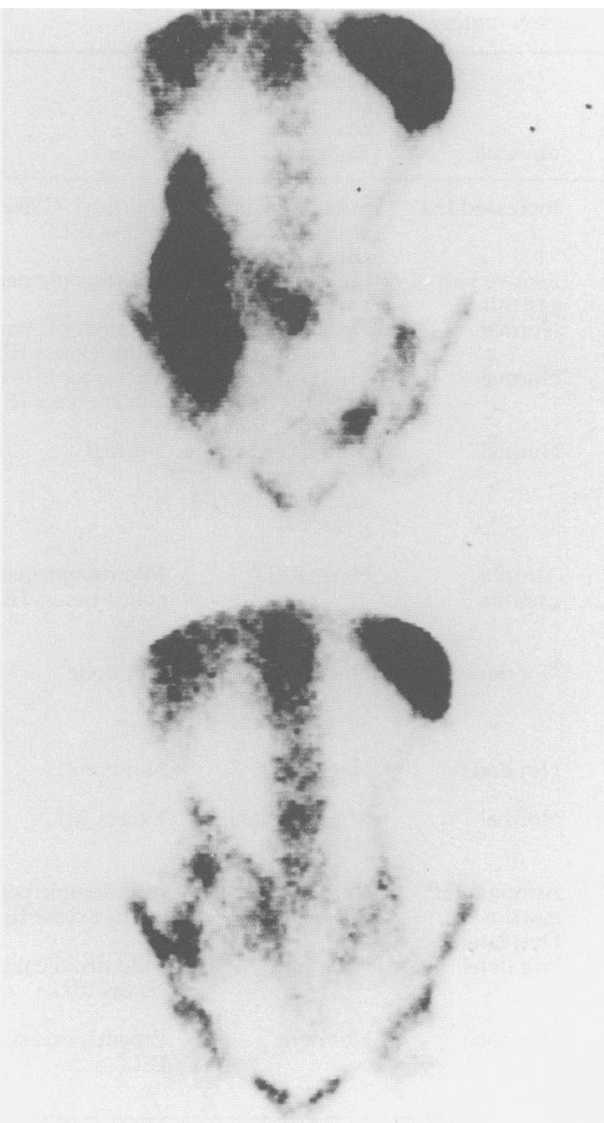

Figure 1: An abdominal "11indium leucocyte scintigram from a patient with primary hypogammaglobulinaemia and diarrhoea (above) showing normal hepatic, splenic, and bony uptake of the labelled cells and an inflamed intestinal segment corresponding to ileum. The lower scintigram shows greatly reduced intestinal inflammation after treatment with elemental diet for four weeks.

\section{HISTOPATHOLOGICAL STUDIES}

Table I shows the main histological findings. In all but one patient, and at all sites, plasma cells were absent or occasional cells found only after prolonged searching. Nine patients had gastric biopsies of which five were normal. Of the four with abnormal biopsies two showed a mild pangastritis, but in two there was severe atrophy in corpus and antrum. Helicobacter

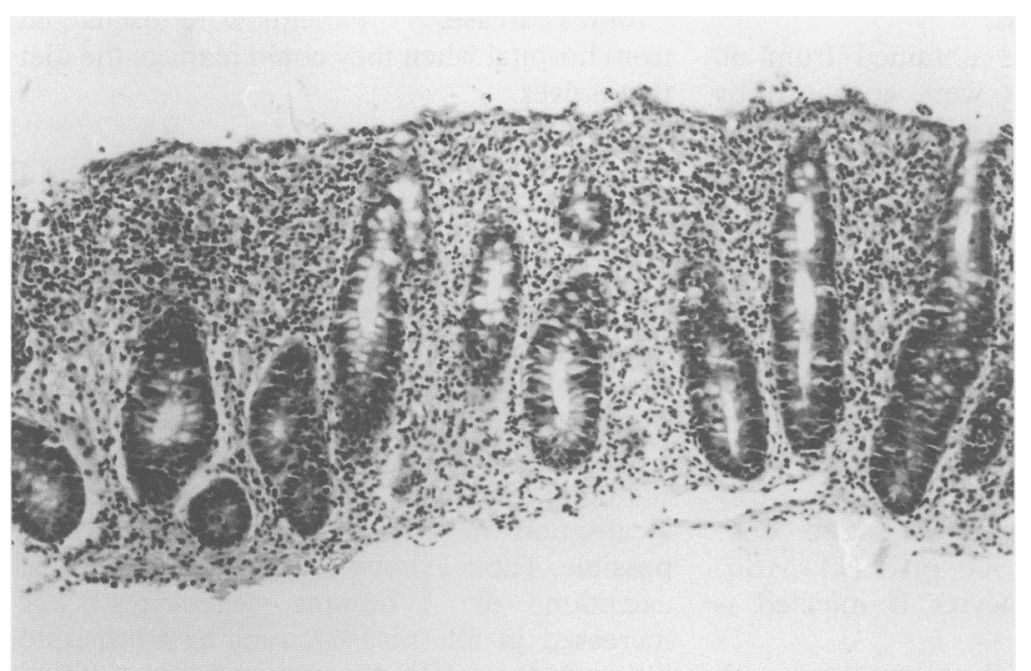

Figure 2: A low grade colitis from a patient with hypogammaglobulinaemia resembling lymphocytic colitis with surface epithelial degeneration and increased numbers of intraepithelial lymphocytes in the cryptal epithelium (haematoxylin and eosin, original magnification $\times 181$ ).

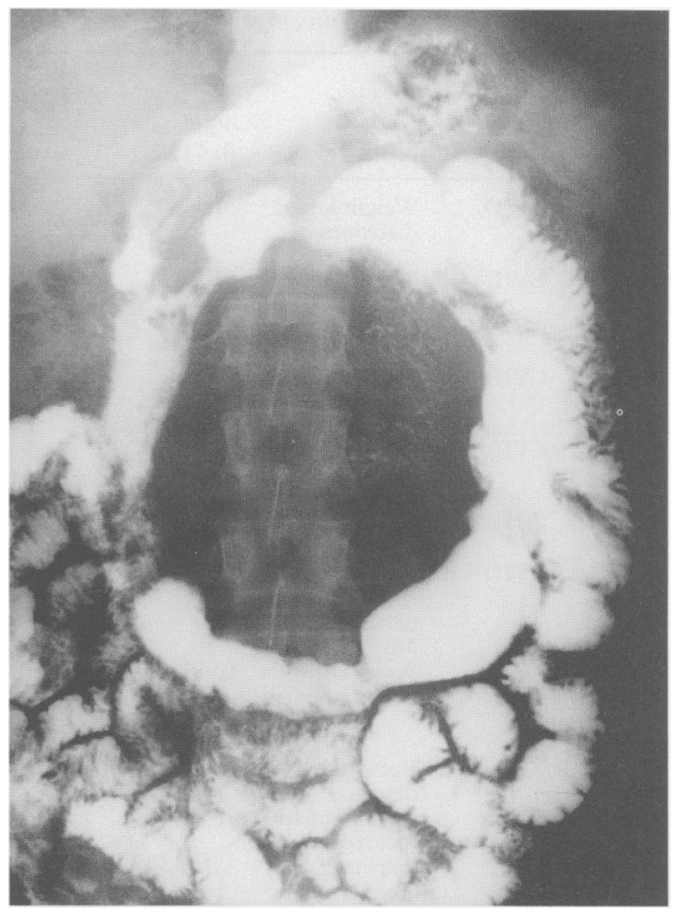

Figure 3: A small intestinal follow through showing jejunal strictures and separated jejunal loops because of a centrally located inflammatory mass.

pylori like organisms were identified in one patient.

Duodenal biopsies were available in eight patients. Two had villous atrophy with raised number of intraepithelial lymphocytes, two showed mild villous atrophy, two were inflamed but had intact villi, and two were normal.

Of the four patients in whom the jejunum was biopsied two were normal and two were flat and both had a positive lactose tolerance test (a flat blood glucose curve after $50 \mathrm{~g}$ of lactose) with diarrhoea. These two patients had had flat duodenal biopsy specimens.

Ten of the patients had a series of colonic biopsies in only one of whom were they normal. In one the picture was indistinguishable from ulcerative colitis apart from the absence of plasma cells and increased number of intraepithelial lymphocytes. In five of the remaining eight there was a total colitis, with the other three showing inflammation restricted to the sigmoid colon and rectum. The inflammation was mild in all cases and mostly restricted to the superficial half of the mucosa. It was predominantly lymphocytic with neutrophil polymorphs and eosinophils. Figure 2 shows the representative histology. In four the numbers of intraepithelial lymphocytes was considerably raised and in three mildly raised. The crypt architecture was intact, and crypt abscesses were not a feature.

Patients 5-7 (Table I) were particularly interesting as they had small intestinal strictures. Figure 3 shows a representative barium follow through from patient 7 (patient no 5 was similar). Loops are separated by an inflammatory mass and there are multiple tight jejunal strictures. The radiological findings are suggestive of Crohn's disease.

Patient 7 had a resection of the diseased intestinal segment and in patient 5 the 


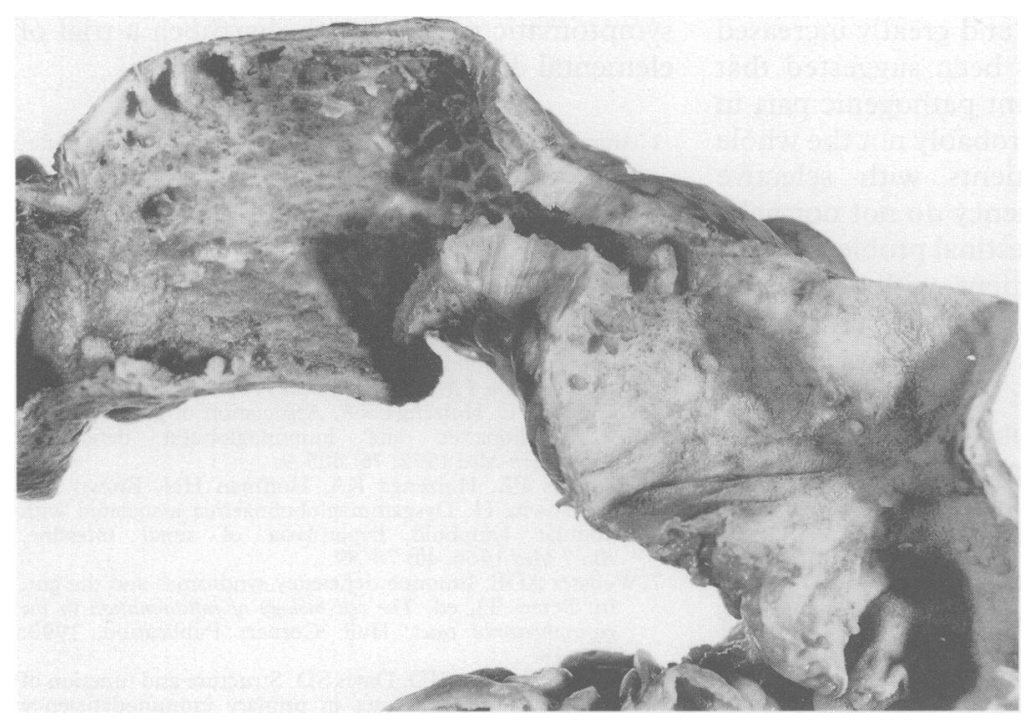

Figure 4: $A$ small intestinal resection segment from a patient with primary hypogammaglobulinaemia. There is a broad based fibrous stricture with proximal ulcers. There are scattered, small inflammatory pseudopolyps.

strictures were shown at necropsy. Figure 4 shows the macro and microscopic appearances. There were multiple broad small intestinal strictures, which were based on submucosal fibrosis, fibromuscular hyperplasia of the muscularis, and a degree of neural hyperplasia. No transmural inflammation or granulomas were seen. Patient 6 had been receiving non-steroidal anti-inflammatory drugs (NSAIDs) for control of rheumatoid arthritis for six years and at ileoscopy characteristic changes of NSAID enteropathy were seen with diaphragm formation. ${ }^{29}$

\section{TREATMENT}

Five patients had mild or intermittent symptoms at the time of study and were not treated. Seven (no 1-7) were treated with an elemental diet and stopped all normal food intake during the four week treatment period. Six patients had a similar response to that seen in acute Crohn's disease 2627 with rapid improvement in well being, loss of lethargy, which was a prominent symptom in most cases, and cessation of diarrhoea. One patient did not improve significantly although the frequency of diarrhoea was reduced. Figure 1 shows a representative abdominal scintigram before and after successful treatment with an elemental diet. In five patients the faecal excretion of ${ }^{111}$ indium was assessed at the end of the treatment period. Table II shows that

TABLE II Effect of elemental diets on intestinal inflammation in patients with primary hypogammaglobulinaemia

\begin{tabular}{lll}
\hline & \multicolumn{2}{l}{$\begin{array}{l}\text { Faecal excretion of } \\
\text { (\%) injected dose) }\end{array}$} \\
\cline { 2 - 3 } Patient no & Before & \\
\hline 2 & 7.2 & After \\
3 & $5 \cdot 9$ & 3.0 \\
5 & 14.5 & 3.9 \\
6 & 12.7 & 5.9 \\
7 & 10.8 & 9.3 \\
& & 1.8 \\
\hline
\end{tabular}

there was a reduction of intestinal inflammation in each case. Repeat gastroduodenoscopy and colonoscopy, however, showed no histological improvement.

Patients 1 and 3 are well at six and 12 months, patient 2 had a relapse at seven months. He started the diet again and is well six months later. Patients 4-7 relapsed within one month of resuming food. One had an intestinal resection, two required large doses of antibiotics, one of whom died from fulminating pneumonia and sepsis. The patient receiving NSAIDs was treated with metronidazole ${ }^{30}$ with a reduction in the faecal excretion of ${ }^{111}$ indium leucocytes from $9 \cdot 7$ to $3.5 \%$ and the diarrhoea is partially controlled with cholestyramine.

\section{Discussion}

Before the introduction of intravenous immunoglobulin treatment, the diarrhoea in many patients with primary hypogammaglobulinaemia was most often associated with Giardia lamblia, campylobacter or salmonella. ${ }^{7}$ Such pathogens are now rarely found in these patients. It is not clear whether protection results from the infused immunoglobulin $G$ appearing in the saliva, or whether it crosses the intestinal mucosa to 'neutralise' luminal organisms. Despite 'high dose' intravenous immunoglobulin treatment, however, chronic severe diarrhoea remains an important clinical problem.

While there were mild and inconsistent histological changes in the stomach and proximal small intestine there was a high prevalence of a low grade colitis. All had an acute enteritis as shown by the $111_{\text {indium }}$ leucocyte studies. Those with abdominal pain as the main feature were found to have luminal obstruction resulting from strictures. Significantly, in the patients with the most severe symptoms, treatment with elemental diet led to considerable, albeit temporarily, improvement in well being.

The upper gastrointestinal histopathological findings are in keeping with that previously reported. The gastritis was without activity in most cases and the jejunal morphological findings were perhaps less noticeable than expected. This contrasts with the frequency of lower small intestinal inflammation and colitis. The ${ }^{111}$ indium leucocyte scintigrams and faecal excretion show that most of these patients have an enteropathy, which has not previously been suspected when investigated by conventional techniques. The inflammatory activity is usually greater than that seen in intestinal infections ${ }^{31}$ and in NSAID induced enteropathy ${ }^{28}$ and is similar to that seen in classic quiescent or moderately active inflammatory bowel disease. ${ }^{26} 28$ The cause of the acute small intestinal inflammation is not evident. In the context of patients with hypogammaglobulinaemia it is tempting to relate the pathogenesis of the inflammation to deficient IgA production and secretion. In patients with Crohn's disease there is decreased (possibly primary) spontaneous 
secretion of mucosal IgA and greatly increased IgG secretion and it has been suggested that this may play an important pathogenic part in the disease. ${ }^{32-34}$ This is probably not the whole story, however, as patients with selective immunoglobulin A deficiency do not normally have significant gastrointestinal problems apart from the occasional patient with coexisting coeliac disease.

The pattern of colitis was always of mild degree, and in all but one, in whom it resembled ulcerative colitis, it fell within the spectrum of microscopic or lymphocytic colitis. ${ }^{3536}$ Characteristically such patients show a total colitis detected only by biopsy. There was a mild low grade inflammatory cell infiltrate throughout the mucosa with very little crypt damage or abscesses. A high proportion showed increased numbers of intraepithelial lymphocytes. Histologically there is some overlap with the condition of collagenous colitis ${ }^{37}$ but no evidence of an increased collagen plate was seen in any of the patients reported here. The aetiology of this pattern of colitis is unknown but there has been speculation about it being an abnormal response to luminal antigens akin to that of coeliac disease, ${ }^{38}$ as a relation between the two has been described. ${ }^{39}$

In the past there may have been a tendency to classify the gastrointestinal changes in patients with hypogammaglobulinaemia into the diagnostic category of classic inflammatory bowel disease, which bears with it the connotation that a change in mucosal immunoglobulin secretion was important in the pathogenesis of ulcerative colitis and Crohn's disease. In this series there was a superficial clinical and radiological resemblance with classic inflammatory bowel disease but the histopathology lacked diagnostic features, apart from one patient who had features of ulcerative colitis. It would seem that hypogammaglobulinaemia is associated, in its own right, with a specific form of intestinal inflammation with variable manifestations.

A consensus has emerged from published works that a gluten free diet is not of particular benefit to symptomatic patients with hypogammaglobulinaemia. Our patients in this category have, however, responded symptomatically to treatment with an elemental diet with significant reductions in the excretion of ${ }^{111}$ indium leucocytes, similar to that seen in Crohn's disease, ${ }^{27}$ but with no significant change in mucosal histology. It would seem that treatment with elemental diets is a valuable temporary measure in severely symptomatic patients with hypogammaglobulinaemia, which should be tried when empirical treatment with antibiotics and corticosteroids have failed.

In summary a high prevalence of small intestinal inflammation and microscopic colitis was found in a group of patients with diarrhoea and hypogammaglobulinaemia treated with intravenous immunoglobulins. The histopathological features suggest a pattern of inflammation distinguishable from classic inflammatory bowel disease. In severely symptomatic patients with diarrhoea a trial of elemental diets may be advisable.

1 Ammann AJ, Hong R. Selective IgA deficiency: presentation of 30 cases and review of the literature. Medicine 1971; 50: 223-36.

2 Asquith P, Thompson RA, Cooke WT. Serum immunoglobulins in adult coeliac disease. Lancet 1969; ii: 129-31.

3 Ament ME. Immunodeficiency syndromes and the gut. Scand F Gastroenterol 1985; 20 (suppl 114): 127-35.

4 Hermans PE, Diaz-Buxo JA, Stobo JD. Idiopathic late onset immunoglobulin deficiency. Clinical observations in 50 patients. Am F Med 1976; 61: 221-37.

5 Hermans PE, Huizenga KA. Association of gastric cancer with idiopathic late immunoglobulin deficiency Ann Intern Med 1972; 76: 605-9.

6 Hermans PE, Huizenga KA, Hoffman HN, Brown AL Markowitz H. Dysgammaglobulinaemia associated with nodular lymphoid hyperplasia of small intestine. Am f Med 1966; 40: 78-89.

7 Webster ADB. Immune deficiency syndromes and the gut. In: Peters TJ, ed. The cell biology of inflammation in the gastrointestinal tract. Hull: Corners Publication, 1990: gastrointesti

8 Ament ME, Ochs HD, Davis SD. Structure and function of the gastrointestinal tract in primary immunodeficiency the gastrointestinal tract in primary immunodeficiency syndrom 2278 .

9 Johnson RL, Van-Arsdel PP, Tobe AD, Ching Y. Adult hypogammaglobulinaemia with malabsorption and iron deficiency anaemia. Am $\mathcal{F}$ Med 1967; 43: 935-43.

10 Binder HJ, Reynolds RD. Control of diarrhoea in secondary hypogammaglobulinaemia by fresh plasma infusion. N Engl f Med 1967; 277: 802-3.

11 Collins JR, Ellis DS. Agammaglobulinaemia, malabsorption and rheumatoid like arthritis. Am f Med 1965; 39: 476-82.

12 Kelkonen R, Siurla M, Vuopio P. Inherited agammaglobulinaemia with malabsorption and marked alterations in the gastrointestinal mucosa. Acta Med Scand 1963; 172. gastrointest

13 Cohen N, Paley D, Janowitz HD. Acquired hypogammaglobulinaemia and sprue. Report of a case and review of the literature. $\mathcal{F} M t$ Sinai Hosp 1969; 28: 421-7.

14 Swift PN. Hypogammaglobulinaemia, steatorrhoea and megaloblastic anaemia. Response to gluten free diet and folic acid. Post Grad Med $\mathcal{F} 1962$; 38: 633-9.

15 Huizenga KA, Wollaeger EE, Green PA, McKenzie BF Serum globulin deficiencies in nontropical sprue with report of two cases of acquired agammaglobulinaemia. Am Med F 1961; 31: 572-80.

16 Dawson J, Bryant MG, Bloom SR, Peters TJ. Jejunal mucosal enzyme activities, regulatory peptides and organelle pathology of the enteropathy of common variable immunodeficiency. Gut 1986; 27: 273-7.

17 Dawson J, Hodgson HJF, Pepys MB, Peters TJ, Chadwick VS. Immunodeficiency, malabsorption and secretory diarrhoea. Am $\mathcal{F}$ Med 1979; 67: 540-6.

18 Diaz-Buxo JA, Hermans PE, Huizenga KA Gastrointestinal dysfunction in immunoglobulin deficiency. Effects of corticosteroid and tetracyclin ҰAMA 1975; 233: 1189-91.

19 Webster AD, Slavin G, Shiner $M$, Platts-Mills TAE, Asherson GL. Coeliac disease with severe hypogammaglobulinaemia. Gut 1981; 22: 153-7.

20 Eggert RC, Wilson ID, Good RA. Agammaglobulinaemia and regional enteritis. Ann Intern Med 1969; 71: 581-5.

21 Abramowsky CR, Sorensen RU. Regional enteritis-like enteropathy in a patient with agammaglobulinaemia: histologic and immunocytological studies. Hum Pathol 1988; 19: 483-6.

22 Soltoft J, Petersen L, Kruse P. Immunoglobulin deficiency and regional enteritis. Scand $\mathcal{f}$ Gastroenterol 1972; 7 : 233-6.

23 Strauss RG, Chisan F, Mitros F, Ebensberger JR, Kisker $\mathrm{CT}$, Tannous $\mathrm{R}$, et al. Rectosigmoidal colitis in common variable immunodeficiency disease. Dig Dis Sci 1980; 25 798-801.

24 Fillit H, Bernstein L, Davidson M, Brandt L, Bezahler G, Cohen M. Primary acquired hypogammaglobulinaemia and regional enteritis. Arch Intern Med 1977; 137: 1252-4.

25 Mir-Madjlessi SH, Tavassolie H, Kamalian N. Malakoplakia of the colon and recurrent colonic strictures in a patient with primary hypogammaglobulinaemia. Dis Colon Rectum 1982; 25: 723-7.

26 Teahon K, Bjarnason I, Pearson M, Levi AJ. Ten years' experience with elemental diet in the management of experience with elemental diet in the

27 Teahon K, Smethurst P, Pearson M, Levi AJ, Bjarnason I The effect of elemental diet on intestinal permeability and The effect of elemental diet on intestinal permeability and 101: 84-9.

28 Bjarnason I, Zanelli G, Smith T, Prouse $P$, Smethurst $P$ Delacey G, et al. Nonsteroidal antiinflammatory drug induced intestinal inflammation in man. Gastroenterology 1987; 93: 480-9.

29 Lang J, Price AB, Levi AJ, Burk M, Gumpel JM, Bjarnason I. Diaphragm disease: the pathology of non-steroidal antiinflammatory drug induced small intestinal strictures. f Clin Pathol 1988; 41: 516-26.

30 Bjarnason I, Hayllar J, Smethurst P, Price AB, Menzies IS, Gumpel MJ. Metronidazole reduces inflammation 
and blood loss in NSAID enteropathy. Gut 1992; 33: 1204-8.

31 Kordossis T, Joseph AEA, Gane JN, Bridges CE, Griffin GE. Fecal leukocytosis, indium-111-labelled autologous polymorphonuclear leucocyte abdominal scanning, and quantitative fecal indium-111 excretion in acute gastroenteritis and enteropathogen carriage. Dig Dis Sci 1988; 33: $1383-90$

32 Bookman MA, Bull DM. Characteristics of isolated intestinal mucosal lymphoid cells in inflammatory bowel disease. Gastroenterology 1979; 77: 503-10.

33 McDermott RP, Delacroik DL, Nash GS, Bertovick MJ, Mohrman RF, Verman JP. Altered patterns of secretion of monomeric IgA and IgA subclass 1 in intestinal mononuclear cells in inflammatory bowel disease. Gastroenterology 1986; 91: 379-85.

34 McDermott RP, Stenson WF. Alterations in the immune system in ulcerative colitis and Crohn's disease. Adv Immunol 1988; 42: 284-328.
35 Kingham JG, Levinson DA, Ball JA, Dawson AM. Microscopic colitis - a cause of chronic watery diarrhoea. BMf 1982; 285: 1601-4.

36 Lazenby AJ, Yardley JH, Giardiello FM, Jessurun J, Bayless TM. Lymphocytic ('microscopic') colitis: a comparative histopathologic study with particular reference to collagenous colitis Hum Pathol 1989; 20: 18-28.

37 Giardiello FM, Lazenby AB, Bayless TM, Levine EJ, Bias WB, Laderson PW, et al. Lymphocytic (microscopic) colitis: a clinicopathological study of 18 patients with comparison to collagenous colitis. Dig Dis Sci 1989; 34: 1730-8.

38 Yardley JH, Lazenby AJ, Giardiello FM, Bayless TM. Collagenous, 'microscopic', lymphocytic, and other gentler and more subtle forms of colitis. Hum Pathol 1992; 21: 1089-91.

39 Wolber R, Owen D, Freeman $H$. Colonic lymphocytosis in patients with celiac sprue. Hum Pathol 1992; 21: 1092-6. 